\title{
EDITORIAL: SHE 41.2 NOVEMBER 2015
}

\section{GOING ONLINE}

During 2015 Studia Historiae Ecclesiasticae ventured - and is still venturing into new territories. It is now a fully-fledged Open Access Journal and has not only survived the transition from manual to digital publishing, but is already established in this area. This transition was a challenge and a learning curve, not only for its editor and sub-editor, but also for the authors who now have to submit and manage their submissions online. We all did well, placing history on its way to the future!

\section{New sub-editor}

This is the second issue of SHE for 2015, and the first one in which its new co-editor, Prof. Mokhele Madise, has participated. Prof. Madise is the Manager for Research and Graduate Studies at the College of Human Sciences, University of South Africa. We invite him into the circle of editing and wish him well with the task ahead.

\section{Editorial Board}

We have appointed and interim Editorial Board, who are Prof Jerry Pillay, Prof Philippe Denis, Prof Mandy Goedhals, Prof Graham Duncan, Prof Mokhele Madise (co-editor) and Prof Christina Landman (editor). Up till now the editor has been assisted by an Advisory Board of international scholars. They commented and advised on the content of SHE annually. The Editorial Board consists of six members, including the editor and co-editor, and the Board meets three times a year to discuss and approve each issue of SHE. At the next AGM of the Church History Society of

\section{UNISA}


Southern Africa in 2016, an Editorial Board will be elected that will remain in office for three years. The Editorial Board will choose the new editor of SHE in 2017.

\section{CONTENT OF THIS ISSUE}

The content of this second issue of SHE for 2015 is particularly interesting. It contains thirteen articles, most of which deal with the contribution of unknown or neglected church leaders, many of whom were not theologians but thinkers in their own right.

The thirteen articles can be divided into four main themes. The first three articles deal with historical contributions of religious leaders, a majority of them from South Africa, who were not professional theologians but whose theological thinking on topical issues is noteworthy. Simangaliso Kumalo and Henry Mbaya wrote on Alpheus Zulu, the first African Bishop of the Anglican Church in South Africa, and his thoughts on racism. Frederick Hale presents Ramsden Balmforth as minister of the Unitarian Church in Cape Town from 1897 to 1937 and his views on the future of religion considering the political and economic situation of South Africa at the time. While Balmforth was "post-orthodox", Ryan McGraw takes us back to the Reformed Orthodoxy of John Owen (1616-1683).

The second part of this issue also contains four articles, this time dealing with the contributions of theologians to the South African society. Nico Botha writes on four black Reformed theologians whose contributions should not be forgotten, namely Takatso Mofokeng, Kkuha Ntoane, Llewellyn Mazamisa and SP Govender. Retief Müller reconsiders Johannes du Plessis in the colonial-indigenous encounter of the previous century. Alfred Brunsdon considers Willem Saayman's mission history from a narrative perspective. And finally, Ndikho Mtshiselwa reads Psalm 23:4 through the eyes of John Wesley for a South African audience.

The third theme centres around the issue of land. In 2013 we remembered that a century ago, in 1913, the notorious Native Land Act alienated blacks from their land, and the following three articles perpetuate this research. Olehile Buffel tells the story of the journey of the people of Bethany from land dispossession to impoverished repossession. Tsepo Lephakga tells a compelling history of how the being of Africans was conquered through land dispossession. And Komi Hiagbe reflects on how the church can be involved in sustainable development in sub-Saharan Africa.

Finally, three articles with a varied focus conclude this issue. Thias Kgatla and FS Mkhwanazi ask the question whether women ministers in the Methodist Church in South Africa are indeed given an equal place in the church. Graham Duncan describes Ethiopianism as a Pan-African phenomenon and Danoye Laguda explores the role of religion in the 2011 presidential elections in Nigeria.

This is indeed an issue that presents new and challenging research, an issue to be proud of. 


\section{SUPPLEMENT}

The final issue of SHE for 2015 will be the Supplement which contains mainly the peer-reviewed papers that were delivered at the 2015 conference of the CHSSA on "Memory", that is, the ways in which people remember.

\section{IN CONCLUSION}

It has been a pleasure, as much as a challenge, to be the Editor-in-Chief of Studia Historiae Ecclesiasticae during these exciting times. I wish to thank all our authors for their contributions and their commitment to make SHE a truly African journal with an international scopus. 